\title{
Semantic Differential for Evaluation of Educational Pathway of Personality
}

\section{Семантичний диференціал для оцінки освітньої траєкторії особистості}

\author{
Yana Sukhenko \\ Ph.D. in Psychology, \\ Postdoctoral student
}

\author{
Яна Сухенко \\ кандидат психологічних наук, \\ докторант
}

\begin{abstract}
E-mail: suhenko333@gmail.com orcid.org/0000-0001-7440-2537

Researcher ID: P-9693-2018
\end{abstract}

\author{
University of Educational \\ Management, National Academy of \\ Educational Sciences of Ukraine \\ $\triangle 52$ A, Sichovykh Striltsiv Str., \\ Kyiv, Ukraine, 04053
}
ДВНЗ «Університет менеджменту освіти» Наиіональної академії педагогічних наук України
$\bowtie$ вул. Січових Стрільців, 52-а, м. Київ, Україна, 04053

Original manuscript received February 06, 2018

Revised manuscript accepted September 06, 2018

\begin{abstract}
The article deals with the issue of personal educational pathway, in particular experimental verification of theoretical ideas of the phenomenon, and the development of the "educational pathway» semantic differential as an adequate tool for its evaluation.

In the course of the experiment, which involved 424 persons, including school and university students and teachers, the "educational pathway» concept descriptors sets were distinguished and processed; the primary matrix of results was composed. It was processed according to two algorithms distinguishing semantic universals, and their advantages were identified. The designed application form of "educational pathway» semantic differential contains 76 scales. Its reliability and partially validity were checked
\end{abstract}


experimentally. The peculiarities of applying this technique and interpreting the results are presented and described in the paper as well.

Based on a factor analysis, there have been distinguished 7 generalized evaluation structures, which are implicitly presented in the educational process parties' minds. The following components make up a system of meanings and attitudes to the educational pathway: implementation conditions, formation mechanisms, management forms, mapping (as a form of the technique and research results representation), individual character, innovative nature of the educational pathway of a personality.

The presented semantic differential helps to examine and accumulate empirical data concerning subjective semantics and experience of personality's lifelong educational pathway realization, contributes to the implementation of Ukrainian educational system reformation ideas based on a student-centered approach. Besides, it enriches the Ukrainian psychodiadnostic techniques database. Further research studies in this area will be dedicated to the peculiarities of the educational pathway in various occupational groups.

Key words: personal educational pathway, psychology of subjective semantics, semantic differential, semantic experiment, semantic environment structure.

\section{Вступ}

Особистісно зорієнтована модель освіти передбачає створення умов для реалізації індивідуальних освітніх траєкторій (IOT) учнів, студентів, слухачів. Зокрема, у Концепції Нової української школи (НУШ) уміння навчатись упродовж життя та вибудовувати власну освітньо-професійну траєкторію визначено однією 3 десяти ключових компетентностей, акцентується увага на роботі за індивідуальними планами, навчальним траєкторіями, дослідницькими проектами, на організації роботи відповідно до індивідуальних стилів, темпу, складності та навчальних траєкторій учнів тощо. Означені пріоритети актуалізують проблему індивідуальної освітньої траєкторії в теорії та практиці підготовки, перепідготовки, підвищення кваліфікації педагогічних, науково-педагогічних працівників як рушіїв і провідників змін в системі освіти України.

Проблема IOT має міждисциплінарний характер. В педагогіці досліджується з акцентом на педагогічних умовах, формах, ресурсах i засобах реалізації на різних рівнях освіти. Сучасний підхід передбачає розроблення системи специфікації IOT у формальній, 
неформальній та інформальній освіті (Janssen, Berlanga, Vogten \& Koper, 2008), характеризується зосередженням уваги на ресурсності е-навчання, довіри, експертних оцінок та їх синергії (Carchiolo, Longheu \& Malgeri, 2010).

У працях американських соціологів освітні траєкторії/шляхи (educational trajectories / pathways) розглядаються 3 акцентом на освітніх переходах (educational transitions), диференціюються семантично споріднені поняття, відповідні аналітичні моделі, підходи до вимірювання (Pallas, 2003); вивчаються можливості використання соціальних мереж, засобів масової інформації для створення індивідуального освітнього середовища, розвитку навичок саморегуляції навчання у студентів в якості інструментів реалізації IOT (Dabbaghe \& Kitsantas, 2011); розроблено типологію освітніх шляхів молоді протягом п'яти років після закінчення школи (Giudici \& Pallas, 2014). У лонгетюдному дослідженні канадськими вченими проаналізовано теоретичні підходи до розуміння сутності феномену освітньої траєкторії, семантику споріднених англомовних понять, референти освітніх траєкторій студентів (Crossan, Field \& Gallacher, 2009).

У психологічних дослідженнях увагу зосереджено на IOT як системному, особистісно значущому утворенні, що відрізняється суб'єктною своєрідністю та стійкістю прояву способів навчальної роботи, як персональному шляху реалізації в освіті особистісного потенціалу учня (Носова, 2009); ціннісно-смислових особливостях, навчальній та професійній мотивації студентів, які навчаються за IOT (Дзюба, 2010); особливостях проектування IOT в системі неперервної освіти (Зеер, 2014); суб'єктній позиції студентів як факторі спроможності та можливості побудови освітньої траєкторії саморозвитку (Радчук, 2015); принципах е-навчання, що створюють можливості для інтелектуального саморозвитку за IOT (Смульсон, 2009); на екофасилітативному супроводі індивідуальної траєкторії розвитку особистості у практиці освітнього процесу (Лушин, 2017).

За результатами міждисциплінарного аналізу проблеми у вітчизняних та зарубіжних дослідженнях розглядаємо IOT: в динамічній єдності освітніх подій, ситуацій та перспектив, які забезпечують постійну трансформацію зон актуального та найближчого розвитку особистості, співвідносяться з загальною структурою освітнього шляху особистості за принципами 
компліментарності, компенсації, стимулювання; у складі таких структуротвірних змістово-функціональних категорій: соціальнопсихологічної, процесуально-динамічної, картографічнохронологічної, освітньо-дидактичної та ресурсної (Сухенко, 2017).

В психологічних дослідженнях вивчаються індивідуальнота соціально-психологічні чинники, психологічні референти, організаційні умови реалізації IOT за допомогою методик діагностики когнітивних, інтелектуальних особливостей, креативності, мотивації, стилю діяльності, ціннісних, сенсожиттєвих орієнтацій. Поглиблений предметний пошук показав, що наразі прямого психодіагностичного інструменту для оцінки освітньої траєкторії особистості не існує, що й спонукало до розроблення спеціалізованого семантичного диференціалу «Освітня траєкторія».

Методи семантичного оцінювання широко застосовуються в психодіагностиці, у сімейному консультуванні, у вивченні феноменів групової згуртованості та дозволяють в якості стимулу розглядати практично будь-які події, ситуації, соціальні ролі, продукти, ставлення (Серкин, 2008). В зарубіжній літературі останніх років увага приділяється: формалізації статистичних процедур i уточненню алгоритму використання семантичного диференціалу в сучасних умовах, зокрема на прикладі маркетингового дослідження в галузі електронної торгівлі (Verhagen, Hooff \& Meents, 2015); модифікації процедури збору даних, введенню категорії невизначеності в семантичний простір, що дозволяє більш адекватно його вивчати (Stoklasa, Talášek \& Stoklasová, 2018); практиці використання семантичного диференціалу в медицині (Mohammed \& Benlamri, 2014).

Семантичний диференціал (СД) є одним з проективних методів психолінгвістичного аналізу, прикладна значущість якого «...полягає у виявленні переважно несвідомих компонентів психіки людини, що активізуються під час сприйняття вербальної інформації та побудови семантичних просторів реципієнтів» (Засєкіна \& Засєкін, 2008). Шкали неспеціалізованих семантичних диференціалів не завжди дозволяють описати стимули з різних предметних галузей, нерідко викликають ускладнення у досліджуваних. Дана проблема вирішується шляхом розроблення спеціальних предметних семантичних диференціалів. 
Мета роботи полягає у поглибленні уявлень про феномен IOT та розробленні спеціалізованого семантичного диференціалу «Освітня траєкторія» (СДОТ) як адекватного інструменту для оцінки освітньої траєкторії особистості (групи).

Ïï досягнення передбачає виконання таких завдань: аналіз наукових джерел 3 проблем індивідуальної освітньої траєкторії та суб'єктивної психосемантики; виділення наборів дескрипторів поняття «освітня траєкторія», їх обробка, впорядкування, узагальнення; проведення експерименту та отримання первинної матриці результатів, iï опрацювання за допомогою процедур виділення семантичних універсалій, факторного аналізу; укладання робочого варіанту, перевірка його надійності, валідності та представлення остаточного варіанту.

\section{Методи та методика дослідження}

При розробленні спеціалізованого СДОТ спираємось на ключові ідеї психології суб'єктивної семантики К. Артемьєвої (Артемьева, 1999) та виходимо з того, що СДОТ має репрезентувати систему смислів, співвіднесену з історією власної освітньої діяльності (як процесу набуття знань, умінь, навичок, компетентностей, так і їх передачі іншим) упродовж життя та зафіксовану у вигляді ставлень до неї. СДОТ розроблено відповідно до алгоритму К. Артемьєвої та Серкіна (Серкин, 2008: 277-280), а також з урахуванням уточнень до нього в частині статистичної обробки та інтерпретації результатів А. Мазуркевича (2013).

На першому етапі роботи проаналізовано тематичні педагогічні, психологічні, соціологічні наукові публікації вітчизняних i зарубіжних дослідників (Сухенко, 2017) та напрацьовано два набори дескрипторів поняття «освітня траєкторія». Перший виділено на основі аналізу фахової літератури, у т.ч. 18-ти найбільш повних i обгрунтованих визначень таких семантично близьких понять як: «освітня траєкторія», «індивідуальна освітня траєкторія», «освітні переходи», «освітній шлях», «індивідуальний освітній маршрут». Для виділення другого набору дескрипторів залучалися учні 11-х класів (56 осіб), студенти (30 осіб), педагогічні працівники (207 осіб). Оскільки, навчальна й освітня діяльність є основною для них, вони виступили експертами та визначили поняття «освітня траєкторія», «індивідуальна освітня траєкторія»; зазначили по 
три відповідні асоціації (слово або словосполучення); описали поняття «освітня траєкторія» та власну освітню траєкторію 3-5 прикметниками.

Об’єднання найбільш вагомих (частотних) дескрипторів (у т.ч. прикметників, дієслів, іменників, прислівників) першого та другого наборів, їхня подальша класифікація, перетворення інших частин мови в прикметники та прислівники, доповнення антонімами, виключення синонімічних дескрипторів дозволила укласти первинний варіант СДОТ, що включає 127 шкал. Для виявлення 3 нього найбільш інформативних i важливих для диференціації шкал було залучено 424 особи (76 учнів, 17 студентів, 331 педагогічний працівник).

Існують певні відмінності у підходах до виділення семантичних універсалій зі стартового набору дескрипторів, пов'язані 3 розумінням поняття «семантична універсалія», вибором статистичних процедур іiі виділення, визначенням ролі методів редукції даних у побудові семантичного простору певного стимулу. Розроблення спеціалізованого СД за алгоритмом В. Серкіна включає виділення групової семантичної універсалії (за середніми значеннями), що однаково оцінюються значущою більшістю (від 75\%) однорідної групи респондентів, та доповнення ii окремими шкалами за результатами факторного та кластерного аналізів (Серкин, 2008: 277-280).

А. Мазуркевич вважає, що семантична універсалія має визначатися за принципами значущості (шкали-дескриптори, що входять до семантичної універсалії мають значуще відрізнятися від тих, які не до неї не потрапляють, визначає їх шляхом порівняння дисперсії кожної шкали з середньою дисперсією за всіма шкалами iз застосуванням F-критерія Фішера), а також зв'язаності (шкалидескриптори мають утворювати певну семантичну єдність, цілісність, що виявляються за допомогою факторного аналізу як засобу виявлення інтегративних структур в системі даних). Виходячи 3 цього визначається ієрархічна структура семантичного простору стимулу: центральний рівень або універсальне ядро опису стимулу утворюють значущі та зв'язані шкали дескриптори, що й розуміються як власне семантичні універсалії; рівень семантичних доповнень - значущі та незв'язані шкали; рівень семантичного фону незначущі та зв’язані шкали; рівень семантичного шуму - незначущі 
та незв'язані шкали. Відповідно, алгоритм включає виділення семантичних універсалій як визначення шкал, варіативність яких має достовірно нижчі значення ніж значення середньої дисперсії за всіма шкалами (за F-критерієм); проведення повної процедури факторного аналізу; виділення ієрархічної структури семантичного простору стимулу (Мазуркевич, 2013: 120-122).

Враховуючи вищезазначене, на етапі експериментальної обробки первинного варіанту СД отримана матриця результатів оцінювання опрацьовувалася за двома варіантами виділення семантичних універсалій: а) за 90\%-им критерієм частоти вибору діапазон розмаху середніх за всіма шкалами - 4,46; 10\%-ий лівий діапазон відступу: від $-2,42$ до -1,97, 10\%-ий правий діапазон відступу: від 1,59 до 2,0 (Серкин, 2008: 261); б) шляхом порівняння дисперсії кожної шкали з середньою дисперсією за всіма шкалами за F-критерієм Фішера (Мазуркевич, 2013: 121-122). До першого варіанту групової семантичної універсалії оцінки освітньої траєкторії потрапили 53 дескриптори; до другого - 34 дескриптори. При цьому 31 дескриптор виявився спільним для обох множин. Проведення паралельних процедур виділення семантичних універсалій дозволяє розглядати статистичну процедуру, запропоновану А. Мазуркевичем як статистично строгішу.

Експериментальна вибірка $є$ достатньою для виявлення та обгрунтування наявності факторів за взаємозв'язками між змінними. Максимальне наближення до простої факторної структури (Наследов, 2004: 271-272) засвідчило доцільність вибору 7-факторного рішення (метод головних компонент, обертання Варімакс, 7 ітерацій, КМО 0,950, Барлета - 0,000), що включає 62 шкали та пояснює 53,6\% сукупної дисперсії.

Найпростішим i допустимим варіантом $\epsilon$ найменування факторів відповідно до назви змінної з найбільшим навантаженням. За такого підходу семантичний простір поняття «освітня траєкторія» може бути описаний факторами: «активність», «натхнення», «сила», «картографія», «конфліктність», «персоналізованість», «стаціонарність». Інший варіант передбачає виявлення загального смислового зв'язку між змінними та відображення його у назві фактору, що й спробуємо зробити 3 метою поглиблення уявлень про досліджуване явище. У нижченаведених описах для простоти сприйняття зазначаємо лише один полюс шкал (визначено 3 
урахуванням знаку факторного навантаження та значення, до якого тяжіє середньо групова оцінка досліджуваних), але в інтерпретаціях маємо на увазі їхній повний діапазон.

До першого фактору (15,03\% дисперсії) увійшло 17 шкал. Тлумачимо його як такий, що репрезентує ставлення до освітньої траєкторії, насамперед, крізь призму активності (0,75 - тут і далі показник навантаження змінної) та розвитку $(0,75)$, що пов'язані зі смислами $(0,75)$, інтелектуальними здібностями $(0,70)$, орієнтаціями особистості $(0,65)$ та змістом $(0,67) ; з$ умовами реалізації/супроводу: кваліфікована $(0,64)$, відповідна $(0,64)$, гуманістична $(0,62)$, сучасна $(0,59)$, нова $(0,58)$, психологічна $(0,56) ; 3$ об'єктивацією та пріоритетністю: актуальна $(0,69)$, здобута $(0,57)$, головна $(0,53)$ існуюча $(0,49)$, хронологічна $(0,54)$. Очевидно, перший фактор репрезентує інтегральну оцінку діалектичної єдності «внутрішніхзовнішніх» умов реалізації освітньої траєкторії (при тому, що внутрішні умови оцінюються досліджуваними як більш вагомі) та iii об’єктивації у хронологічному вимірі, тому позначаємо його як «умови реалізації освітньої траєкторії».

У другому факторі (14,17\% дисперсії) угрупувалося 18 шкал. Примітно, що наведені оціночні ставлення співвідносяться 3 традиційними уявленнями про структурно-функціональну організацію особистості в єдності: емоційної грані - надихаюча $(0,72)$, зручна $(0,69)$, прогресивна $(0,65)$, корисна $(0,62)$, ресурсна $(0,63)$; когнітивної - розумна $(0,64)$; вольової - зосереджена $(0,70)$, довільна $(0,57)$; мотиваційно-результуючої - компетентна $(0,57)$, успішна $(0,57)$; темпоральної - швидка $(0,64)$. Якщо в оцінках освітньої траєкторії віддзеркалюється особистість, то освітня траєкторія може розглядатися як проекція особистості в зовнішньому плані, а іiі просторово-розмірні оцінки - висока $(0,69)$, широка $(0,53)$, об'єднана $(0,54)$ - як метафорична суб'єктивна оцінка «освітніх меж». Тоді й роль шкал, які відображають співвіднесеність освітньої траєкторії, ii ризоматичність, динамічність у часі - притаманна $(0,55)$, альтернативна $(0,54)$, майбутня $(0,65)$, чітка $(0,58)$, в «проективному» факторі стає зрозумілою та логічною. Відображення внутрішньої структури особистості, її динамічного психологічного портрету у «контурах» освітньої траєкторії на «екрані» освітнього простору асоціюється 3 процесом екстеріоризації за Л. Виготським. Але, розглядати порізно 
процеси інтеріоризації-екстеріоризації можна лише в теорії. Тому в «живому» контексті та широкому значенні розуміємо даний фактор як такий, що імпліцитно характеризує загальний соціокультурний механізм формування та реалізації освітньої траєкторії. ІОТ як унікальний шлях пізнання себе та інших/світу виникає там i тоді, де і коли процеси інтеріоризаціїекстеріоризації резонують i породжують «зону найближчого розвитку» для себе та інших/світу. Навчаючись - навчаємо... Таке діалектичне розуміння сутності індивідуального шляху здобуття освіти підтверджує іiі соціальну природу та відповідає сучасним тенденціям розуміння навчання як недирективного, фасилітативного, екопсихологічного процесу, що має розвивальний потенціал для усіх залучених. Отже, фактор, який несе на собі відбиток психологічного портрету суб'єкта освітньої траєкторії, виявляє діалектику та соціокультурний механізм іiі формування, що забезпечується процесами інтеріоризації та екстеріоризації, позначаємо в психологічних термінах як «механізми формування освітньої траєкторії».

Третій фактор (12,14\% дисперсії) поєднав 14 шкал i насамперед зчитується як «сила керованості» або «керована сила»: сильна $(0,76)$, керована $(0,72)$. В психології таке поєднання співвідноситься зі здатністю до саморегуляції, самоуправління як вищими психологічними функціями особистості: усвідомлена $(0,64)$, функціональна $(0,61)$, регулятивна $(0,57)$, стратегічна $(0,63)$; 3 ознаками досягнення мети та результативності: сформована $(0,68)$, цілісна $(0,66)$, результативна $(0,61)$, впевнена $(0,64)$, зрозуміла $(0,63)$, конкретна $(0,54)$, реалістична $(0,52)$, повна $(0,50)$. Даний фактор називаємо «саморегуляція освітньої траєкторії».

Наступні чотири фактори мають нижчий відсоток дисперсії, але також доповнюють уявлення про систему смислів, пов'язаних 3 траєкторіями та історіями освітньої діяльності досліджуваних. Четвертий фактор (3,57\% дисперсії) представлений шкалами: картографічна $(0,73)$, топологічна $(0,64)$, нетопографічна $(-0,63)$, біологічна $(0,52)$. Прикладами використання картографічного підходу в психології $\epsilon$ розширена картографія психіки С. Грофа як докладний феноменологічний опис різних рівнів, типів переживань (Оксфордский толковый словарь о психологии, 2002), нова картографія поля світової психотерапії В. Цапкіна (Цапкин, 2009). Топологічна психологія К. Левіна відображає структурну 
модель особистості у взаємодії 3 навколишнім середовищем і вирішує задачу графічного представлення концепції «динамічного поля» (Lewin, 1936). Топографічна модель особистісної організації 3. Фрейда $\epsilon$ вертикальною метафорою психічного апарату в єдності свідомості, підсвідомості, несвідомого. Топографія поведінки наразі широко використовується в роботі з дітьми 3 аутизмом, зокрема, у прикладному аналізі поведінки (Applied Behavior Analysis) i передбачає операційний iï опис (Webster, 2018). П. Лушин розглядає психологічну топографію освіти як унікальне поєднання внутрішніх засобів, способів, умов діяльності для досягнення поставленої освітньої мети в певних заданих зовнішніх умовах; як специфічність руху/розвитку особистості на освітній мапі місцевості; як психолого-педагогічну технологію, що зумовлює дидактичну потребу в постійному перевизначенні, довизначенні навчального змісту в конкретних умовах (Лушин, 2017).

Сукупність даних шкал інтерпретуємо як свідчення структурованості IOT, можливості іiі моделювання та графічного унаочнення в одному 3 форматів: топографічному (процесуальнолокаційному), топологічному, картографічному. Суть останнього лаконічно формулює В. Цапкін у контексті переосмислення основних концептів світової психотерапії: «Оскільки суть будь-якої картографії полягає в тому, щоб об'єднати дещо подібне в одну групу та чітко відокремити іiі від неподібного, то завдання даного дослідження - знайти не тільки єдність поля світової психотерапії, але й відокремити, розділити, не завуалювати, а наочно показати його принципову розщепленість і позначити лінії розколів. Лінії цих розколів і утворюють основні контури картографії світової психотерапії» (Цапкин, 2009: 175). Найменш навантаженою в четвертому факторі $є$ шкала «біологічна-небіологічна». Вірогідно, вона може розглядатися в якості тієї самої «лінії розколу» або коректніше - лінії, що поєднує полюси природничої та гуманітарної парадигм (Братусь, 2005) і у вимірі постмодерної науки визначає найширший діапазон дослідження освітньої траєкторії особистості на підгрунті «лібералізації» методології. По суті, «демаркаційний» фактор проявляє роль методологічної основи в дослідженні освітньої траєкторії особистості як психологічного феномену, засвідчує можливість і варіанти іiі репрезентації у міждисциплінарному та метафоричному вимірах. До речі, метафора за логікою 
психосемантики розглядається як міжсистемне перенесення, що забезпечує перехід від однієї до іншої категоріальної системи, від однієї класифікації об’єктів світу до іншої (Артемьева, 1999: 124). Іменуємо цей фактор як «картографія освітньої траєкторії».

П'ятий фактор (3,31\% дисперсії) увібрав шкали: безконфліктна $(0,68)$, неперервна $(0,67)$, системна $(0,65)$. Вони акцентують якісну неоднорідність освітньої траєкторії: наявність стабільних (неперервних, системних) і перехідних (переривчастих, хаотичних) періодів; конфліктності, що у філософському розумінні асоціюється 3 точкою нового відліку, «переходу», джерелом розвитку (або на іншому полюсі - застою). Феномени освітньої траєкторії та життєвого шляху особистості за сукупністю даних шкал уподібнюються та вірогідно можуть досліджуватися на предмет конгруентності. Позначаємо фактор як «характер освітньої траєкторії».

До наступного фактору (2,71\% дисперсіi) потрапили шкали персональна $(0,76)$, самостійна $(0,65)$, спільна $(-0,59)$. Вони можуть сприйматися як синонімічні, але на етапі первинної обробки жодну 3 них не виключено, оскільки, у своєму повному діапазоні кожна відображає специфічну грань прояву індивідуального та соціального в контексті набуття освіти. Це підтвердили й учасники дослідження під час уточнюючих консультацій щодо зрозумілих/ незрозумілих назв шкал. Угрупування та виокремлення цих шкал 3-поміж інших свідчить про значущість фактору «персоналізованість освітньої траєкторії».

Сьомий фактор (2,67\% дисперсії) описує певний сегмент семантичного простору освітньої траєкторії в уявленнях та ставленні досліджуваних трьома шкалами (з урахуванням знаку факторного навантаження): дистанційна $(0,57)$, несподівана $(0,44)$, диференційована $(0,29)$, при цьому оцінки респондентів за середніми значеннями зміщені до полюсів: стаціонарна, очікувана, диференційована. Діалектичний зв'язок диференціації та інтеграції навчання розкривається у понятті «інтедифія освіти» В. Моргуна та розуміється як «...пульсуючий взаємоперехід між інтеграцією та диференціацією змісту освіти, методів навчання i виховання, навчально-виховних закладів, що обумовлюється як потребами й можливостями суспільства, так і здібностями, інтересами особистості. Або, як коротко визначає філософ, взаємоперехід між «порядком i хаосом» у собі» (Моргун, 1996). Логічно 
припустити, що таке поєднання шкал викриває варіативність досвіду набуття освіти та характеризує освітню траєкторію у вимірі інноваційності/традиційності (змісту, форм, методів, засобів, технологій освіти тощо).

Цінність факторного аналізу зумовлюється й можливістю обчислення значень факторів та використання їх як нових інтегральних змінних 3 мінімальною втратою початкової інформації у подальших дослідженнях.

\section{Результати та дискусії}

Проведена робота дозволила укласти чотирирівневу структуру семантичного простору поняття «освітня траєкторія» у складі: центрального рівня - універсального ядра опису стимулу, рівня семантичних доповнень, рівня семантичного фону, рівня семантичного шуму (в таблиці 1 зазначено полюси шкал, до яких тяжіє середня групова оцінка, іiї абсолютне значення).

Таблиця 1. Структура семантичного простору поняття «освітня траєкторія»

\section{РІВНI СТРУКТУРИ}

\begin{tabular}{|c|c|c|c|}
\hline $\begin{array}{l}\text { Семантичні } \\
\text { універсалії }\end{array}$ & $\begin{array}{l}\text { Семантичні } \\
\text { доповнення }\end{array}$ & Семантичний фон & Семантичний шум \\
\hline $\begin{array}{l}\text { активна } 2,4 \\
\text { актуальна } 2,4 \\
\text { гуманістична 2,1 } \\
\text { здобута } 2,0 \\
\text { змістовна } 2,3 \\
\text { зрозуміла } 2,1 \\
\text { інтелектуальна 2,2 } \\
\text { існуюча 2,0 } \\
\text { кваліфікована 2,2 } \\
\text { орієнтована 2,1 } \\
\text { прогресивна } 1,7 \\
\text { результативна 2,0 } \\
\text { розвивальна 2,3 } \\
\text { сформована } 1,9 \\
\text { функціональна 2,0 } \\
\text { хронологічна 2,1 } \\
\text { цілісна 2,1 }\end{array}$ & $\begin{array}{l}\text { висхідна } 1,9 \\
\text { виховна } 2,2 \\
\text { відповідальна } 2,3 \\
\text { достатня } 2,0 \\
\text { здійсненна } 2,0 \\
\text { конструктивна 2,0 } \\
\text { культурна 2,3 } \\
\text { логічна 2,2 } \\
\text { максимальна 2,0 } \\
\text { методична 2,2 } \\
\text { цікава 2,0 } \\
\text { особистісна 2,1 } \\
\text { пізнавальна 2,4 } \\
\text { приємна 2,0 } \\
\text { професійна 2,2 } \\
\text { розроблена } 1,9 \\
\text { стабільна 2,1 } \\
\text { толерантна 2,1 }\end{array}$ & $\begin{array}{l}\text { альтернативна } 1,5 \\
\text { безконфліктна } 1,4 \\
\text { розумна } 1,9 \\
\text { успішна } 1,8 \\
\text { біологічна } 1,6 \\
\text { відповідна } 2,0 \\
\text { впевнена } 2,0 \\
\text { широка } 1,3 \\
\text { надихаюча } 1,6 \\
\text { головна } 1,9 \\
\text { стаціонарна } 0,2 \\
\text { диференційована } 0,2 \\
\text { картографічна } 0,8 \\
\text { керована } 1,8 \\
\text { конкретна } 1,9 \\
\text { довільна } 0,8 \\
\text { майбутня } 1,3 \\
\text { зручна } 1,5\end{array}$ & $\begin{array}{l}\text { вольова } 1,6 \\
\text { діяльнісна } 1,8 \\
\text { обумовлена } 0,6 \\
\text { цілеспрямована } 2,0 \\
\text { важка } 1,0 \\
\text { варіативна } 1,3 \\
\text { велика } 1,8 \\
\text { глибока } 1,8 \\
\text { динамічна } 1,5 \\
\text { довга } 1,7 \\
\text { доросла } 1,3 \\
\text { задана } 1,5 \\
\text { захоплююча } 1,9 \\
\text { зовнішня } 0,5 \\
\text { соціальна } 0,1 \\
\text { індуктивна } 0.0 \\
\text { інноваційна } 1,2 \\
\text { комунікативна } 2,2\end{array}$ \\
\hline
\end{tabular}


Семантичний диференціал для оцінки освітньої траєкторії...

$\begin{array}{ll}\text { компетентна } 1,8 & \text { пряма } 0,6 \\ \text { неперервна } 1,4 & \text { набута } 1.0 \\ \text { притаманна } 1,4 & \text { навчальна } 0,7 \\ \text { очікувана } 0,3 & \text { наполеглива } 2,0 \\ \text { топографічна } 0,6 & \text { необмежена } 1,3 \\ \text { висока } 1,5 & \text { послідовна } 1,6 \\ \text { нова } 2,0 & \text { педагогічна } 2,3 \\ \text { колективна } 0,2 & \text { об'ємна } 1,4 \\ \text { швидка } 1,1 & \text { постійна } 1,9 \\ \text { повна } 1.9 & \text { практична } 1,8 \\ \text { психологічна 2,1 } & \text { пристосована } 1,6 \\ \text { реалістична } 1,6 & \text { просторова } 1,3 \\ \text { регулятивна } 1,6 & \text { радісна } 1,9 \\ \text { об'єднана } 1,2 & \text { творча } 1,2 \\ \text { чітка } 1,5 & \text { різна } 2,1 \\ \text { зосереджена } 1,4 & \text { розгалужена } 1,1 \\ \text { групова } 0,1 & \text { розповсюджена } 1,0 \\ \text { сильна } 1,9 & \text { своя } 1,9 \\ \text { системна } 1,7 & \text { складна } 0,9 \\ \text { смислова } 2,3 & \text { спеціальна } 0,3 \\ \text { спільна } 1,0 & \text { об'єктивна } 0,4 \\ \text { ресурсна } 1,4 & \text { суміщена } 1,4 \\ \text { стратегічна } 1,9 & \text { суперечлива } 0,1 \\ \text { сучасна } 2,0 & \text { тривимірна } 1,4 \\ \text { топологічна } 0,9 & \text { унікальна } 1,0 \\ \text { усвідомлена } 1,2 & \text { життєва } 1,2 \\ \text { корисна } 2,0 & \text { формальна } 0,5 \\ & \text { хороша } 2,1 \\ \text { природна } 0,9 \\ \end{array}$

До робочого варіанту СДОТ увійшли шкали центрального рівня, рівнів семантичних доповнень і фону (всього 80 шкал). Оцінку внутрішньої узгодженості (вибірка стандартизації 78 осіб) здійснено за коефіцієнтом альфа Кронбаха $(0,89)$; розщепленої надійності - за коефіцієнтом Гутмана $(0,72)$; ретестової - шляхом повторного тестування за 4 тижні, оцінка за коефіцієнтом Гутмана $(0,85)$. За відсутності релевантних перевірених семантичних диференціалів, опитувальників і шкал часткова перевірка валідності проведена за методом контрастних груп: групові семантичні універсалії власної освітньої траєкторії досліджуваними чоловічої статі (85 особа) та жіночої статі (139 осіб) різняться за 65 шкалами (критерій Манна-Уітні, $\mathrm{p}<0,05$ ), що підтверджує чітко виражені диференційні властивості робочого бланку СДОТ. 
Semantic Differential for Evaluation of Educational Pathway...

За результатами додаткового опитування респондентів 3 робочого варіанту СДОТ виключено шкали, що виявилися складними: «регулятивна-дерегулятивна», «спустошуюча-ресурсна», «топологічна - нетопологічна»; шкалу «стратегічна-безпланова», що високо корелює ( $\mathrm{r}=0,81, \mathrm{p}=0,001)$ зі шкалою «сформовананесформована», як менш інформативну; уточнено та змінено назви шкал: «розсіяна - зосереджена» на «розпорошена - зосереджена», «культурна - невихована» на «культурна - некультурна», «існуюча неіснуюча» на «реальна - неіснуюча». Остаточний бланк СДОТ налічує 76 шкал, його представлено в додатку.

При аналізі результатів СДОТ варто враховувати, що метод семантичних універсалій дозволяє виявити явну структуру даних, визначає перелік значущих дескрипторів для семантичної універсалії стимулу, факторний аналіз - імпліцитну, тому їх співставлення збільшує інформативність. Аналіз результатів може включати як окремі процедури (виділення семантичних універсалій, факторний аналіз), так i їх сукупність. Обробка результатів СДОТ може здійснюватися як за алгоритмом виділення семантичних універсалій (Серкин, 2008: 258-264), так і за алгоритмом А. Мазуркевича (Мазуркевич, 2013: 121-122). Проведення паралельних статистичних процедур показало, що алгоритм А. Мазуркевича є статистично строгішим, надає ширші можливості для інтерпретації результатів, тоді як алгоритм К. Артемьєвої та В. Серкіна є відносно простішим для реалізації.

Діагностичні можливості СДОТ дозволяють: визначати та порівнювати індивідуальні освітні траєкторії досліджуваних осіб (груп) крізь призму їх суб’єктивного досвіду; моніторити зрушення, що відбуваються внаслідок зміни умов, змісту, цілей, технологій навчання; вимірювати показники смислової згуртованості групи, а також доповнюються його розвивально-просвітницьким потенціалом. Семантичний контроль ефективності відповідного навчання може здійснюватися через вимір зсуву семантичних кодів, окремих кординат або вторинних харакетристик. СДОТ може використовуватися для виділення групових універсалій оцінки освітньої траєкторії - списку шкал, що однаково оцінюються переважною більшістю однорідної групи досліджуваних, порівняння та аналізу універсалій оцінки різних осіб (груп) 3 
Семантичний диференціал для оцінки освітньої траєкторії...

акцентом на шкалах, які різняться, можливих причинах збігів i розбіжностей; виділення факторної структури оцінки, порівняння та аналізу факторної структури оцінки різних осіб (груп) 3 акцентом на відмінностях; укладання семантичного простору поняття «освітня траєкторія», його аналізу та порівняння для різних груп досліджуваних.

\section{Висновки}

Проведена робота дозволила поглибити теоретичні уявлення про досліджуваний феномен, співвіднести їх 3 емпіричними результатами та доповнити. Визначено, що в уяві суб'єктів освітнього процесу імпліцитно представлені сім оціночних структур, які утворюють систему смислів і ставлень до освітньої траєкторії: умови реалізації, механізми формування, форми управління, картографія (як форма репрезентація методології та результатів дослідження), характер, персоналізованість та інноваційність освітньої траєкторії особистості.

Розроблений СДОТ включає 76 шкал, дозволяє експериментально досліджувати та акумулювати емпіричні дані щодо суб'єктивних семантик і досвіду реалізації освітніх траєкторій особистості упродовж життя, має розвивальний та діагностичний потенціал у плані підготовки науково-педагогічних і педагогічних кадрів до реалізації власних освітніх траєкторій та супроводу індивідуальних освітніх траєкторій учнів, студенів, слухачів; сприяє реалізації ідей реформування освітньої галузі України на засадах особистісно зорієнтованого підходу, поповнює україномовний банк психодіагностичних інструментів.

Перспективи подальших досліджень пов'язуємо з реалізацією тренінгового навчання з теми «Психологія супроводу індивідуальної освітньої траєкторії педагогічного працівника», оцінкою його результативності за СДОТ, 3 апробацією СДОТ в інших професійних групах. 


\section{Додаток}

СЕМАНТИЧНИЙ ДИФЕРЕНЦІАЛ «ОСВІТНЯ ТРАЕКТОРІЯ»

Інструкція. Вкажіть, будь ласка, Вашу стать вік професію дату заповнення

Оцініть, будь ласка, Вашу освітню траєкторію за допомогою запропонованих пар слів. Пари слів позначають протилежні характеристики освітньої траєкторії.

Обведіть ту цифру, яка, на Вашу думку, найбільш точно визначає ступінь вираження даної характеристики у Вашій освітній траєкторії: 0 - не виражена, 1 - слабо виражена, 2 - помірно виражена, 3 - сильно виражена.

Наприклад, Ви обираєте 3 пари «динамічна - статична» характеристику «динамічна» й вважаєте, що Ваша освітня траєкторія $\epsilon$ дуже динамічною. Тоді Ви обводите цифру 3, що знаходиться ближче до слова «динамічна».

Просимо Вас не пропускати пари слів і зробити свій вибір у кожній парі. Необхідно оцінювати Вашу освітню траєкторію лише одним словом із кожної пари.

\section{Бланк спеціалізованого СД «Освітня траєкторія»}

\begin{tabular}{|lllllllllr}
\hline 1. & неперервна & 3 & 2 & 1 & 0 & 1 & 2 & 3 & переривчаста \\
2. & методична & 3 & 2 & 1 & 0 & 1 & 2 & 3 & неметодична \\
3. & головна & 3 & 2 & 1 & 0 & 1 & 2 & 3 & побічна \\
4. & нова & 3 & 2 & 1 & 0 & 1 & 2 & 3 & стара \\
5. & відповідна & 3 & 2 & 1 & 0 & 1 & 2 & 3 & неналежна \\
6. & розвивальна & 3 & 2 & 1 & 0 & 1 & 2 & 3 & деградуюча \\
7. & смислова & 3 & 2 & 1 & 0 & 1 & 2 & 3 & безглузда \\
8. & хронологічна & 3 & 2 & 1 & 0 & 1 & 2 & 3 & нехронологічна \\
9. & активна & 3 & 2 & 1 & 0 & 1 & 2 & 3 & пасивна \\
10. & безальтернативна & 3 & 2 & 1 & 0 & 1 & 2 & 3 & альтернативна \\
11. & здійсненна & 3 & 2 & 1 & 0 & 1 & 2 & 3 & неможлива \\
12. & здобута & 3 & 2 & 1 & 0 & 1 & 2 & 3 & втрачена \\
13. & орієнтована & 3 & 2 & 1 & 0 & 1 & 2 & 3 & дезоріснтована \\
14. & кваліфікована & 3 & 2 & 1 & 0 & 1 & 2 & 3 & некваліфікована \\
15. & некомпетентна & 3 & 2 & 1 & 0 & 1 & 2 & 3 & компетентна \\
16. & конструктивна & 3 & 2 & 1 & 0 & 1 & 2 & 3 & 3 \\
17. & шкідлива & 3 & 2 & 1 & 0 & 1 & 2 & 3 & деструктивна \\
18. & логічна & 3 & 2 & 1 & 0 & 1 & 2 & 3 & корисна \\
& & & & & & & &
\end{tabular}


19. максимальна

20. стабільна

21. розроблена

22. толерантна

23. розмита

24. системна

25. спільна

26. виховна

27. самостійна

28. сучасна

29. гуманістична

30. особистісна

31. достатня

32. розпорошена

33. незручна

34. професійна

35. розмежована

36. культурна

37. реалістична

38. гнітюча

39. повна

40. приємна

41. повільна

42. регресивна

43. конкретна

44. результативна

45. сильна

46. сформована

47. усвідомлена

48. безуспішна

49. функціональна

50. цілісна

51. зрозуміла

52. впевнена

53. актуальна

54. нетопографічна

55. безтолкова

56. несподівана

57. висхідна

58. відповідальна

59. змістовна

60. реальна

61. біологічна

62. нецікава

63. низька $\begin{array}{lllllll}3 & 2 & 1 & 0 & 1 & 2 & 3\end{array}$

$\begin{array}{lllllll}3 & 2 & 1 & 0 & 1 & 2 & 3\end{array}$

3210123

3210123

$\begin{array}{lllllll}3 & 2 & 1 & 0 & 1 & 2 & 3\end{array}$

$\begin{array}{lllllll}3 & 2 & 1 & 0 & 1 & 2 & 3\end{array}$

$\begin{array}{lllllll}3 & 2 & 1 & 0 & 1 & 2 & 3\end{array}$

3210123

3210123

$\begin{array}{lllllll}3 & 2 & 1 & 0 & 1 & 2 & 3\end{array}$

$\begin{array}{llllll}32 & 1 & 0 & 123\end{array}$

$\begin{array}{llllll}3 & 2 & 1 & 0 & 1 & 2\end{array}$

$\begin{array}{lllllll}3 & 2 & 1 & 0 & 1 & 2 & 3\end{array}$

$\begin{array}{lllllll}3 & 2 & 1 & 0 & 1 & 2 & 3\end{array}$

$\begin{array}{lllllll}3 & 2 & 1 & 0 & 1 & 23\end{array}$

3210123

$\begin{array}{lllllll}3 & 2 & 1 & 0 & 1 & 2 & 3\end{array}$

$\begin{array}{lllllll}3 & 2 & 1 & 0 & 1 & 2 & 3\end{array}$

$\begin{array}{llllll}32 & 1 & 0 & 123\end{array}$

32110123

3210123

$\begin{array}{llllll}32 & 1 & 0 & 123\end{array}$

$\begin{array}{llllll}32 & 1 & 0 & 123\end{array}$

$\begin{array}{llllll}3 & 2 & 1 & 0 & 1 & 23\end{array}$

$\begin{array}{lllllll}3 & 2 & 1 & 0 & 1 & 2 & 3\end{array}$

$\begin{array}{llllll}32 & 1 & 0 & 123\end{array}$

$\begin{array}{llllll}32 & 1 & 0 & 1 & 23\end{array}$

$\begin{array}{lllllll}3 & 2 & 1 & 0 & 1 & 23\end{array}$

$\begin{array}{lllllll}3 & 2 & 1 & 0 & 1 & 2 & 3\end{array}$

$\begin{array}{lllllll}3 & 2 & 1 & 0 & 1 & 2 & 3\end{array}$

$\begin{array}{lllllll}3 & 2 & 1 & 0 & 1 & 2 & 3\end{array}$

3210123

$\begin{array}{llllll}3 & 2 & 1 & 0 & 1 & 2\end{array}$

$\begin{array}{lllllll}3 & 2 & 1 & 0 & 1 & 2 & 3\end{array}$

3210123

$\begin{array}{llllll}3 & 2 & 1 & 0 & 1 & 2\end{array}$

3210123

$\begin{array}{lllllll}3 & 2 & 1 & 0 & 1 & 2 & 3\end{array}$

$\begin{array}{lllllll}3 & 2 & 1 & 0 & 1 & 2 & 3\end{array}$

$\begin{array}{lllllll}3 & 2 & 1 & 0 & 1 & 2 & 3\end{array}$

3210123

$\begin{array}{lllllll}3 & 2 & 1 & 0 & 1 & 2 & 3\end{array}$

$\begin{array}{lllllll}3 & 2 & 1 & 0 & 1 & 2 & 3\end{array}$

$\begin{array}{llllll}32 & 1 & 0 & 123\end{array}$

3210123 мінімальна

нестабільна

нерозроблена

інтолерантна

чітка

хаотична

особиста

невиховна

групова

застаріла

декларативна

безособова

недостатня

зосереджена

зручна

непрофесійна

об'єднана

некультурна

ідеалістична

надихаюча

порожня

неприємна

швидка

прогресивна

невизначена

безрезультатна

слабка

несформована

несвідома

успішна

нефункціональна

поодинока

незрозуміла

невпевнена

неактуальна

топографічна

розумна

очікувана

низхідна

безвідповідальна

беззмістовна

неіснуюча

небіологічна

цікава

висока 
Semantic Differential for Evaluation of Educational Pathway...

$\begin{array}{ll}\text { 64. } & \text { минула } \\ 65 . & \text { пізнавальна } \\ 66 . & \text { психологічна } \\ 67 . & \text { маніпулятивна } \\ 68 . & \text { інтелектуальна } \\ 69 . & \text { безконфліктна } \\ 70 . & \text { диференційована } \\ 71 . & \text { вузька } \\ 72 . & \text { картографічна } \\ 73 . & \text { керована } \\ 74 . & \text { дистанційна } \\ 75 . & \text { непритаманна } \\ 76 . & \text { персональна } \\ & \end{array}$

32110123

$\begin{array}{lllllll}3 & 2 & 1 & 0 & 1 & 2 & 3\end{array}$

$\begin{array}{lllllllllll}3 & 2 & 1 & 0 & 1 & 2 & 3\end{array}$

$\begin{array}{llllllllll}3 & 2 & 1 & 0 & 1 & 2 & 3\end{array}$

$\begin{array}{lllllllllll}3 & 2 & 1 & 0 & 1 & 2 & 3\end{array}$

$\begin{array}{llllllllll}3 & 2 & 1 & 0 & 1 & 2 & 3\end{array}$

$\begin{array}{lllllllllll}3 & 2 & 1 & 0 & 1 & 2 & 3\end{array}$

$\begin{array}{llllllllll}3 & 2 & 1 & 0 & 1 & 2 & 3\end{array}$

$\begin{array}{llllllllll}3 & 2 & 1 & 0 & 1 & 2 & 3\end{array}$

$\begin{array}{llllllllll}3 & 2 & 1 & 0 & 1 & 2 & 3\end{array}$

$\begin{array}{lllllllllll}3 & 2 & 1 & 0 & 1 & 2 & 3\end{array}$

$\begin{array}{llllllllll}3 & 2 & 1 & 0 & 1 & 2 & 3\end{array}$

$\begin{array}{llllll}3 & 2 & 1 & 0 & 1 & 2\end{array}$

\author{
майбутня \\ непізнавальна \\ непсихологічна \\ довільна \\ неінтелектуальна \\ конфліктна \\ інтегрована \\ широка \\ некартографічна \\ некерована \\ стаціонарна \\ притаманна \\ колективна
}

\section{Література}

Артемьева, Е.Ю. Основы психологии субъективной семантики / Под ред. И.Б. Ханиной. Москва : Наука ; Смысл, 1999. 350 с.

Братусь, Б.С. Естественнонаучная и гуманитарная парадигмы в психологии: преемственность или скачок. Известия ЮФУ. Технические науки. 2005. T. 51. № 7. C. 3-8.

Дзюба, Е.А. Внутренняя дифференциация как фактор формирования индивидуальных образовательных траекторий студентов : автореф. дисс. ... канд. психол. наук : 19.00.07. Ростов-на-Дону, 2010. 23 с.

Засєкіна, Л.В., Засєкін, С.В. Психолінгвістична діагностика. Луцьк : РВВ «Вежа», 2008. $188 \mathrm{c}$.

Зеер, Э.Ф. Индивидуальные образовательные траектории в системе непрерывного образования. Педагогическое образование в России. 2014. № 3. С. 74-82.

Лушин, П.В. Хаос и неопределенность: от страдания - к росту и развитию. Киев : «Орияна», 2017. 160 с.

Мазуркевич, А.В. Процесуальная конкретизация и математическое обоснование метода семантических универсалий. Вестник КРАУНЦ. Серия «Гуманитарные науки». 2013. № 1(21). С. 112-123.

Моргун, В.Ф. Інтеграція та диференціація освіти: особистісний та технологічний аспекти. ПостМетодика. 1996. № 4(14). С. 41-45.

Наследов, А.Д. Математические методы психологического исследования. Анализ и интерпретация данных. Санкт-Петербург : Речь, 2004. 392 с.

Носова, Е.П. Психолого-педагогические условия выявления и поддержки индивидуальной образовательной траектории ученика : дисс. ... канд. психол. наук : 19.00.07. Москва, 2009. 142 с.

Оксфордский толковый словарь по психологии / Под ред. А. Ребера. В 2-х тт. Т. 1. [Пер. с англ. Е.Ю. Чеботарева]. Москва : Вече АСТ, 2003. 592 с.

Петренко, В.Ф. Основы психосемантики. Санкт-Петербург : Питер, 2005. 480 с.

Радчук, Г.К. Психологія аксіогенезу особистості у контексті вищої професійної освіти. Особистість у розвитку: психологічна теорія $i$ практика: монографія / За ред. С.Д. Максименка, В.Л. Зливкова, С.Б. Кузікової. Суми : Вид-во СумДПУ імені А.С. Макаренка, 2015. 430 с. 
Серкин, В.П. Методы психологии субъективной семантики и психосемантики. Москва : Изд-во ПЧЕЛА, 2008. 382 с.

Смульсон, М.Л. Інтелектуальний саморозвиток у віртуальному освітньому середовищі: зміна парадигми. Актуальні проблеми психології: Психологічна теорія і технологія навчання. / За ред. С.Д. Максименка, М.Л. Смульсон. Київ : Вид-во НПУ імені М.П. Драгоманова, 2009. Т. 8. Вип. 6. 332 с.

Сухенко, Я.В. Індивідуальна освітня траєкторія: міждисциплінарний аналіз феномену. Науковий вісник Херсонського державного університету. Серія «Психологічні науки». 2017. Вип. 4. Том 2. С. 111-116.

Цапкин, В.Н. К новой картографии психотерапевтического поля. Tpyдbl no психологическому консультированию и психотерапии. 2009. № 2. С. 172-192.

Carchiolo, V., Longheu, A., \& Malgeri, M. (2010). Reliable peers and useful resources: Searching for the best personalised learning path in a trust- and recommendationaware environment. Journal Information Sciences, 180(10), 1893-1907. doi10.1016/j.ins.2009.12.023

Crossan, B., Field, J., Gallacher, J., \& Merrill, B. (2003). Understanding participation in learning for non-traditional adult learners: Learning careers and the construction of learning identities. British Journal of Sociology of Education, 24(1), 55-67. http://dx.doi.org/10.1080/01425690301907

Dabbaghe, N.A., \& Kitsantas, A. (2012). Personal Learning Environments, social media, and self-regulated learning: A natural formula for connecting formal and informal learning. Internet and Higher Education, 15, 3-8.

Giudici, F., \& Pallas, A. (2014). Social origins and post-high school institutional pathways: A cumulative dis/advantage approach. Social Science Research, 44, 103-113. DOI:10.1016/j.ssresearch.2013.11.004

Janssen, J., Berlanga, A., Vogten, H., \& Koper, R. (2008). Towards a learning path specification. International journal of continuing engineering education and life long learning, 18(1), 77-97.

Lewin, K. (1936). Principles of Topological Psychology. New York : McGraw-Hill.

Mohammed, O., \& Benlamri, R. (2014). Developing a Semantic Web Model for Medical Differential Diagnosis Recommendation. Journal of Medical Systems, 38, 79. DOI:10.1007/s10916-014-0079-0

Pallas, A. (2003). Educational transitions, trajectories, and pathways. In J. Mortimer \& M. Shanahan (Eds.), Handbook of the Life Course (pp. 165-184). New York : Kluwer Academic/Plenum Publishers.

Stoklasa, J., Talasek, T., \& Stoklasova, J. (2018). Semantic differential for the twenty-first century: scale relevance and uncertainty entering the semantic space. Quality \& Quantity, 35, 1-14. http://dx.doi.org/10.1007/s11135-018-0762-1

Verhagen, T., van den Hooff, B., \& Meents, S. (2015). Toward a better use of the semantic differential in is research: an integrative framework of suggested action research. Journal of the Association for Information Systems, 16(2), 108-143. DOI: $10.17705 / 1$ jais.00388

Webster, Jerry. The Topography of Behavior. URL: thoughtco.com/topography-ofbehavior-3110854.

\section{References}

Artemeva, E.Yu. (1999). Osnovy psihologii subektivnoj semantiki [Fundamentals of the psychology of subjective semantics]. In I.B. Hanina (Ed.). Moscow : Nauka; Smysl [in Russian]. 
Bratus, B.S. (2005). Estestvennonauchnaya i gumanitarnaya paradigmy $\mathrm{v}$ psihologii: preemstvennost' ili skachok [Natural science and humanitarian paradigms in psychology: continuity or leap]. Izvestiya YUFU. Tekhnicheskie nauki - Izvestiya SFedU. Engineering Sciences, 51(7), 3-8 [in Russian].

Dzyuba, E.A. (2010). Vnutrennyaya differenciaciya kak faktor formirovaniya individual'nyh obrazovatel'nyh traektorij studentov [Internal differentiation as a factor in the formation of students personal educational trajectories]. Extended abstract of candidate's thesis. Rostov-na-Donu [in Russian].

Zasiekina, L.V., \& Zasiekin S.V. (2008). Psykholinhvistychna diahnostyka [Psycholinguistics Diagnostics]. Lutsk : RVV «Vezha» [in Ukrainian].

Zeer, E.F. (2014). Individualnye obrazovatelnye traektorii $\mathrm{V}$ sisteme nepreryvnogo obrazovaniya [Individual educational trajectories in the system of continuous education]. Pedagogicheskoe Obrazovanie v Rossii - Pedagogical Education in Russia, 3, 74-82 [in Russian].

Lushin, P.V. (2017). Haos i neopredelennost: ot stradaniya - $k$ rostu i razvitiyu [Chaos and ambiguity: from suffering to growth and development]. Kyiv : Oriyana [in Russian].

Mazurkevich, A.V. (2013). Procesualnaya konkretizaciya i matematicheskoe obosnovanie metoda semanticheskih universalij [Processual specification and mathematic grounding of semantic universals method]. Vestnik KRAUNC. Seriya "Gumanitarnye nauki» - Journal Collection of Scientific Works of KRASEC. The Humanities, 1(21), 112-123 [in Russian].

Morhun, V.F. (1996). Intehratsiia ta dyferentsiatsiia osvity: osobystisnyi ta tekhnolohichnyi aspekty [Integration and differentiation of education: personal and technological aspects]. Post Metodyka - Post Methodology, 4(14), 41-45 [in Ukrainian].

Nasledov, A.D. (2004). Matematicheskie metody psihologicheskogo issledovaniya. Analiz i interpretaciya dannyh [Mathematical methods of psychological research. Data analysis and interpretation]. Sankt-Peterburh: Rech [in Russian].

Nosova, E.P. (2009). Psihologo-pedagogicheskie usloviya vyyavleniya i podderzhki individualnoj obrazovatelnoj traektorii uchenika [Psychological and pedagogical conditions for identifying and supporting the student's individual educational trajectory]. Candidate's thesis. Moscow [in Russian].

Rebera, A. (Ed.). (2003). Oksfordskij tolkovyj slovar' po psihologii [Oxford Dictionary of Psychology]. (Vols. 1-2). (E.Yu. CHebotareva, Trans.). Moscow : Veche [in Russian].

Petrenko, V.F. (2005). Osnovy psihosemantiki [Basics of psychosemantic]. SanktPeterburh : Piter [in Russian].

Radchuk, H.K. (2015). Psykholohiia aksiohenezu osobystosti u konteksti vyshchoi profesiinoi osvity [Psychology of the person's axiogenesis in the context of higher professional education]. Osobystist u rozvytku: psykholohichna teoriia $i$ praktyka: monohrafiia - Personality in development: psychological theory and practice: monograph. Sumy: SumDPU [in Ukrainian].

Serkin, V.P. (2008). Metody psihologii subektivnoj semantiki i psihosemantiki [Methods of psychology of subjective semantics and psycho-semantics]. Moscow : Pchela [in Russian].

Smulson, M.L. (2009). Intelektualnyi samorozvytok u virtualnomu osvitnomu seredovyshchi: zmina paradyhmy [Intellectual self-employment in the virtual educational environment: changing paradigm]. Aktualni Problemy Psykholohii: 
Семантичний диференціал для оиінки освітньӧ̈ траєкторії...

Psykholohichna Teoriia $i$ Tekhnolohiia Navchannia - Actual Problems of Psychology: Psychological Theory and Technology of Learning, 8, 6. Kyiv : NPU [in Ukrainian].

Sukhenko, Ya.V. (2017). Indyvidualna osvitnia traiektoriia: mizhdystsyplinarnyi analiz fenomenu [Personal learning path: cross-disciplinary analysis of phenomen]. Naukovyi Visnyk Khersonskoho Derzhavnoho Universytetu. Seriia "Psykholohichni Nauky» - Scientific Bulletin of the Kherson State University. Series «Psychological Sciences», 4(2), 111-116 [in Ukrainian].

Capkin, V.N. (2009). K novoj kartografii psihoterapevticheskogo polya [To the new mapping of the psychotherapeutic field]. Trudy po psihologicheskomu konsultirovaniyu $i$ psihoterapii - Works on psychological counseling and psychotherapy, 2, 172-192 [in Russian].

Carchiolo, V., Longheu, A., \& Malgeri, M. (2010). Reliable peers and useful resources: Searching for the best personalised learning path in a trust- and recommendationaware environment. Journal Information Sciences, 180(10), 1893-1907. doi10.1016/j.ins.2009.12.023

Crossan, B., Field, J., Gallacher, J., \& Merrill, B. (2003). Understanding participation in learning for non-traditional adult learners: Learning careers and the construction of learning identities. British Journal of Sociology of Education, 24(1), 55-67. http://dx.doi.org/10.1080/01425690301907

Dabbaghe, N.A., \& Kitsantas, A. (2012). Personal Learning Environments, social media, and self-regulated learning: A natural formula for connecting formal and informal learning. Internet and Higher Education, 15, 3-8.

Giudici, F., \& Pallas, A. (2014). Social origins and post-high school institutional pathways: A cumulative dis/advantage approach. Social Science Research, 44, 103-113. DOI:10.1016/j.ssresearch.2013.11.004

Janssen, J., Berlanga, A., Vogten, H., \& Koper, R. (2008). Towards a learning path specification. International journal of continuing engineering education and life long learning, 18(1), 77-97.

Lewin, K. (1936). Principles of Topological Psychology. New York : McGraw-Hill.

Mohammed, O., \& Benlamri, R. (2014). Developing a Semantic Web Model for Medical Differential Diagnosis Recommendation. Journal of Medical Systems, 38, 79. DOI:10.1007/s10916-014-0079-0

Pallas, A. (2003). Educational transitions, trajectories, and pathways. In J. Mortimer \& M. Shanahan (Eds.), Handbook of the Life Course (pp. 165-184). New York : Kluwer Academic/Plenum Publishers.

Stoklasa, J., Talasek, T., \& Stoklasova, J. (2018). Semantic differential for the twentyfirst century: scale relevance and uncertainty entering the semantic space. Quality \& Quantity, 35, 1-14. http://dx.doi.org/10.1007/s11135-018-0762-1

Verhagen, T., van den Hooff, B., \& Meents, S. (2015). Toward a better use of the semantic differential in is research: an integrative framework of suggested action research. Journal of the Association for Information Systems, 16(2), 108-143. DOI: $10.17705 / 1$ jais.00388

Webster, Jerry. The Topography of Behavior. URL: thoughtco.com/topography-ofbehavior-3110854 


\section{АНОТАЦІЯ}

Стаття присвячена проблемі індивідуальної освітньої траєкторії особистості, зокрема, експериментальному уточненню теоретичних уявлень про даний феномен $і$ розробленню спеціалізованого семантичного диференціалу "Освітня траєкторія" як адекватного інструменту його оцінки.

Під час експерименту, учасниками якого стали 424 особи (учні, студенти, педагоги), виділено набори дескрипторів поняття "освітня траєкторія»; укладено первинну матрицю результатів; опрацьовано ії за двома алгоритмами виділення семантичних універсалій, визначено переваги кожного з них. Укладено бланк спеціалізованого семантичного диреренціалу "Освітня траєкторія», що містить 76 шкал, перевірено його надійність, частково валідність. Описано особливості застосування даної методики та інтерпретації результатів.

На основі факторного аналізу виділено 7 узагальнених оціночних структур, які імпліцитно представлені в уяві суб'єктів освітнього прочесу, утворюють систему смислів і ставлень до освітньої траєкторії: умови реалізації, механізми формування, форми управління, картографія (як форма репрезентація методології та результатів дослідження), характер, персоналізованість, інноваційність освітньої траєкторії особистості.

Семантичний диреренціал дозволяє експериментально досліджувати та акумулювати емпіричні дані щодо суб'єктивних семантик $i$ досвіду реалізації освітніх траєкторій особистості упродовж життя, сприяє реалізачії ідей реформування освітньої галузі України на засадах особистісно зорієнтованого підходу, поповнює україномовний банк психодіагностичних інструментів. Дослідницькі перспективи пов'язуємо з вивченням особливостей освітньої траєкторії у представників різних професійних груп.

Ключові слова: індивідуальна освітня траєкторія, психологія суб'єктивної семантики, семантичний диреренціал, семантичний експеримент, структура семантичного простору.

\section{Сухенко Яна. Семантический дифреренциал для оценки образовательной траектории личности}

\section{АННОТАЦИЯ}

Статья посвящена проблеме индивидуальной образовательной траектории личности, в частности, экспериментальному уточнению теоретических представлений о данном феномене и разработке специализированного семантического дифреренциала 
Семантичний диференціал для оичінки освітньої траєкторії...

«Образовательная траектория» как адекватного инструмента его оценивания.

В ходе эксперимента, участниками которого стали 424 человека (старшеклассники, студенты, педагоги), выделены наборы дескрипторов понятия "образовательная траектория»; получена первичная матрица результатов, которая статистически обработана по двум алгоритмам выделения семантических универсалий $и$ на этом основании определены преимущества каждого из них. Составлен бланк специализированного семантического дифрференциала "Образовательная траектория", содержащий 76 шкал, проверена его надежность и частично валидность. Описаны особенности применения методики, интерпретации результатов.

Факторный анализ позволил выделить 7 обобщенных оценочных структур, которые имплицитно содержаться в представлениях субъектов образовательного процесса и образуют систему смыслов и отношений к образовательной траектории: условия реализации, механизмы формирования, формы управления, картография (как форма репрезентации методологии и результатов исследования), характер, персонализированность, инновационность образовательной траектории личности.

Представленный семантический дифреренциал позволяет экспериментально исследовать и аккумулировать эмпирические данные о субъективных семантиках и опыте реализации образовательных траекторий личности, способствует реализации идей ресормирования системы образования Украины на основе личностно-ориентированного подхода, пополняет украиноязычный банк психодиагностического инструментария. Исследовательские перспективы связываем с изучением особенностей образовательной траектории у представителей других профессиональных групп.

Ключевые слова: индивидуальная образовательная траектория, психология субъективной семантики, семантический дифференциал, семантический эксперимент, структура семантического пространства. 